12th LUMEN International Scientific Conference Rethinking Social Action. Core Values in Practice | RSACVP 2019 | 15-17 May 2019 | lasi-

Romania

\title{
Develop Vertical Jump to Junior Volleyball Players by Plyometric Special Means
}

\author{
Adin-Marian COJOCARU, Marilena COJOCARU \\ https://doi.org/10.18662/lumproc.152
}

How to cite: Cojocaru, A.-M., \& Cojocaru, M. (2019). Develop Vertical Jump to Junior Volleyball Players by Plyometric Special Means. In C. Ignatescu (ed.), 12th LUMEN International Scientific Conference Rethinking Social Action. Core Values in Practice, 15-17 May 2019, Iasi - Romania (pp. 49-56). Iasi, Romania: LUMEN Proceedings. https://doi.org/10.18662/lumproc.152 



\title{
Develop Vertical Jump to Junior Volleyball Players by Plyometric Special Means
}

\author{
Adin-Marian COJOCARU1, Marilena COJOCARU2*
}

Abstract

Volleyball is part of the explosion-based sport, fast in a very short time [10]. Vertical jump is extremely important both phases of attack and in the defense [6]. So attack and block 45\% of all game action, and in terms of the achievement points, they represent $80 \%$ [11].

For this, it is important to develop effective training programs that will increase the ability of jumpers to volleyball by coaches. In order to achieve these programs, they need to get information on physical issues in general and volleyball in particular [12].

The main goal was to structure a set of exercises and implement them in volleyball training at the juniors level in order to develop the performance indexes of the vertical jump.

Hypothesis research is we assume that by introducing a specially designed exercise complex, we can record higher vertical jump indexes at final testing compared to the initial test.

The plyometric method was used to develop the vertical jump, and the methods of research were the method of data organization and presentation, the graphic method, the mathematical-statistical method, the classification/ordination method, the comparison/reporting method.

The conclusions of the research were that, following the implementation of the vertical jump development program, the working hypothesis was confirmed, is an increase in vertical jump specific parameters.

Keywords: Vertical jump; Volleyball; Juniors; Plyometric.

\section{Introduction}

A modern training means a new mentality, both from the coaches and the athletes, and the change of mentality means the shift from the imperative quantity to the desideratum of quality and efficiency, in other words it is necessary to achieve a revival, we might even say reform, regarding introducing the principles of praxiology, which provide strong arguments for

\footnotetext{
${ }^{1}$ Spiru Haret University, Bucharest, Romania, adincojocaru@yahoo.com.

2 Spiru Haret University, Bucharest, Romania, marilenacojocaru73@yahoo.com. 
the restructuring of the methodological concepts for the training of high performance athletes [4].

All the qualities and skills of the individual are in complex relationships both with each other and between them and the efficiency of the game action. They change differently in the sport training process and guide us in their fair appreciation. The most important level is when the indexes that show a higher growth from one stage to the next, as well as the interconnection of this increase with that of the efficiency of this game [8]).

he main objectives of the volleyball training are to develop the sport's performance capability, which is achieved through the development of the quality of motorcycle specific volleyball [5].

Volleyball is part of the explosion-based sport, fast in a very short time [10]. The vertical jump represents the majority of these actions [6]. Attack and block actions make $45 \%$ of the total of the game's actions and in terms of the achievement points, they represent $80 \%$ [11].

\section{Problem Statement}

Vertical jump is a combination of two qualities, speed and strength, manifested in as short a time as possible, maximizing the power of the muscle, making an explosion [9].

The level of vertical jumping depends on the number and speed at which neuro-muscular units are involved. Muscle mass is determined by the number of muscle fibers recruited so that speed can allow an early entry into training if the athlete has a good level of development. So you can work to develop this quality.

Plyometric training consists mainly of chain jumping and jumping combinations in all forms.

This training method is an ideal coupling between positive positive training and negative dynamic training.

Due to the variety of exertions, especially the possibilities of changing the working angles, the plyometric allows for the improvement of speed and force, including athletes who are already trained, the plyometric, mainly operating on the stretch/shortening cycle, which occurs almost in all movements of the body in during exercise.

The volleyball game, having predominantly speed and skill, combined motor quality called detention, will have to be a priority, speed or force.

Defeated motor quality in volleyball is reported at the highest point of striking the ball in the attack action during a volleyball game, which is the essence of this research. 
In order to achieve these programs, they need to get information on physical issues in general and volleyball in particular [12].

When using this training method, specialists recommend taking into account the level of training of the athlete and the intensity used in exercises. As with all phases of physical training, plyometric training must be subject to constant progress in the intensity and difficulty of exercises.

\section{Aims of the research}

The main goal was to structure a complex of exercises and implement them in volleyball training at the juniors level, in order to develop performance indicators of detention.

The working hypothesis

We assume that by introducing a specially designed exercise complex, we can record higher indices of detente, final testing compared to the initial.

\section{Research Methods}

- Method of organizing and presenting data

- Graphics method

- The mathematical-statistical method

- Classification / ordering method

- Comparison / reporting method

\section{Organizing and conducting research}

Sample of subjects

The subjects of this research are the composition of the national women's volleyball team juniors (table nr.1):

Table 1 Subjects data

\begin{tabular}{cccc}
\hline Nr. & Name and surname & $\begin{array}{c}\text { Year of } \\
\text { birth }\end{array}$ & $\begin{array}{c}\text { Height } \\
\text { (cm.) }\end{array}$ \\
\hline 1. & B.I.A. & 2002 & 182 \\
2. & C M.I. & 2004 & 186 \\
3. & D.C. I. & 2001 & 183 \\
4. & D.M. & 2002 & 180 \\
5. & I.D.I. & 2002 & 188 \\
6. & M.C. & 2000 & 176
\end{tabular}


Adin-Marian COJOCARU et al. | Lumen Proceedings 9 | RSACVP2019

\begin{tabular}{cccc}
7. & M.F. & 2002 & 181 \\
8. & M.K. & 2002 & 182 \\
9. & N.A.C. & 2001 & 178 \\
10. & V.D.T. & 2001 & 176 \\
\hline
\end{tabular}

The present study was conducted between 01.08.2018 and 31.10.2018 and covered the following stages:

1. Initial testing: 01 August 2018;

2. Implementing the training program: august - October 2018;

3. Final testing: 31 October 2018.

A training program for the development of detention was applied, which focused on the development of the thigh and calf muscles and the plyometric exercises

Exercise 1: Standing away from the shoulder $(20 \mathrm{~kg}$.$) Held on the shoulders,$ looking ahead obliquely upwards, a semi-flexion followed by a vertical jump;

Exercise 2: Standing away in the semi-squats (10 kg sand on the body), the arms stretched back, looking downwards obliquely, running Side levers with the left / right shoulder in the direction of travel;

Exercise 3. Jumps up and down on the gym $(50 \mathrm{~cm})$ and maintaining the final position $(2 \mathrm{sec}$.) With half-knees and palms on the face;

Exercise 4: Downhill from the gym on the ground, on the strong leg, successively long with the other leg and sprint in the distance of $10 \mathrm{~m}$
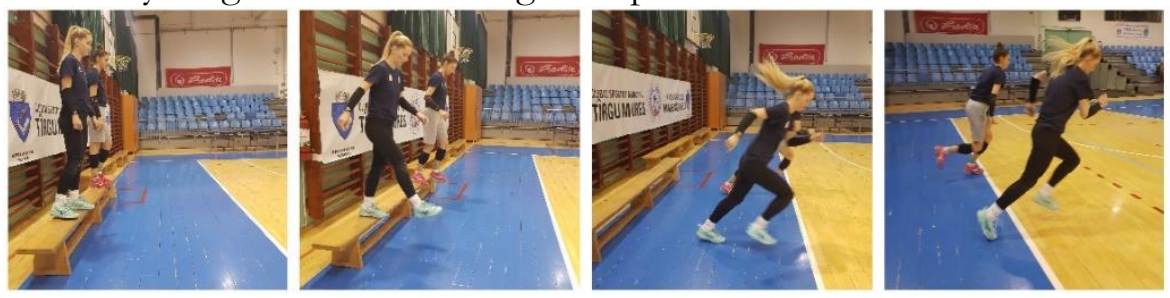

Fig. Exercise 4

Exercise 5: Standing away from the gym (up to $50 \mathrm{~cm}$ ), jumping on the cover, landing balanced on both legs, then jumping with the arm's upper arm and stretching them up, landing balanced on the ground, ping, damping, bending the knees and holding for 5 seconds 

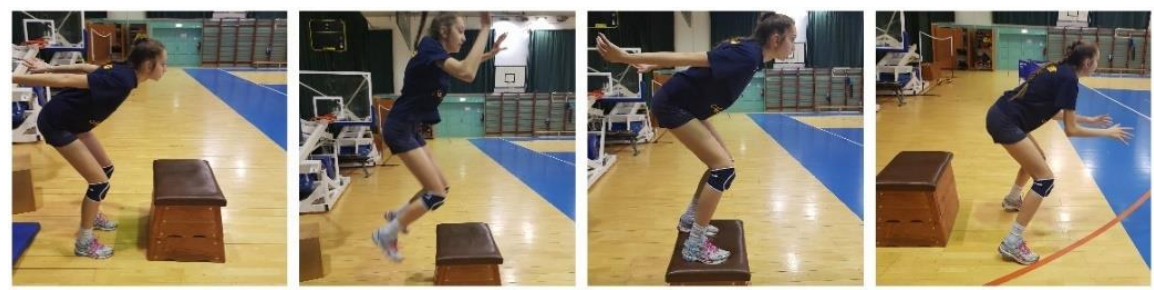

Fig. Exercise 5

Exercise 6: High jump, successive over obstacles, landing in a medium balanced position, keeping the position for at least 5 seconds;
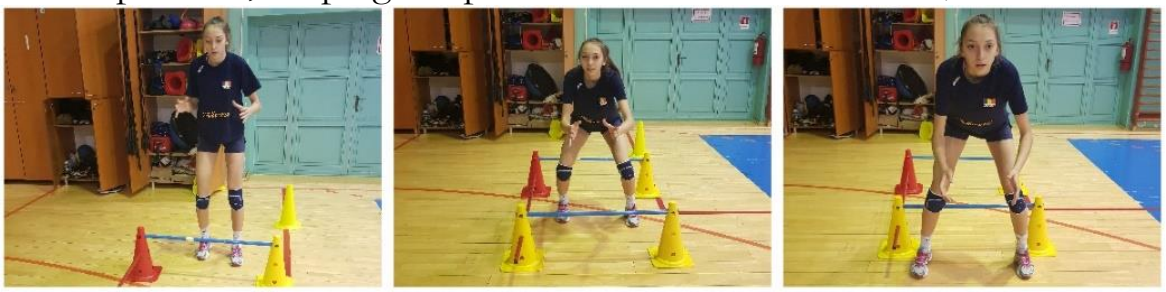

Fig. Exercise 6

Exercise 7: From a distance, knees slightly bent, arms around the body, lightly elbowed, legs on both sides of the Bosu ball, balanced jump with both legs on the ball, high jump and landing with damping in front of the ball in a fundamental position low, holding 5 seconds.
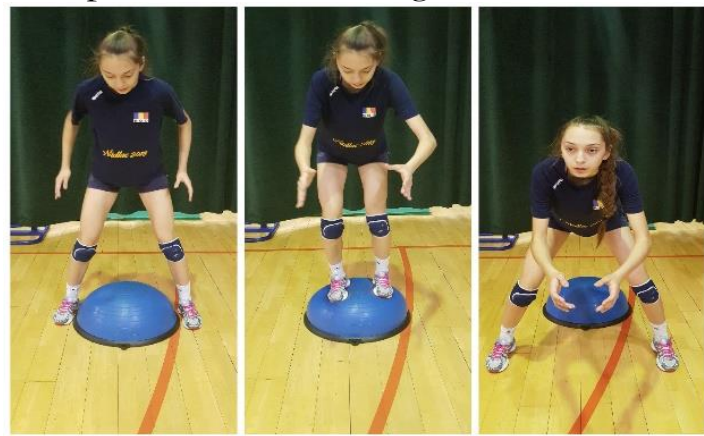

Fig. Exercise 7

Exercise 8: Jumping on the gym bench, controlling the other side down on the strong foot, jumping on the second gym bench, maximum jump, balanced landing on both legs, at the average fundamental position, preparing the arms and jump to the block. 

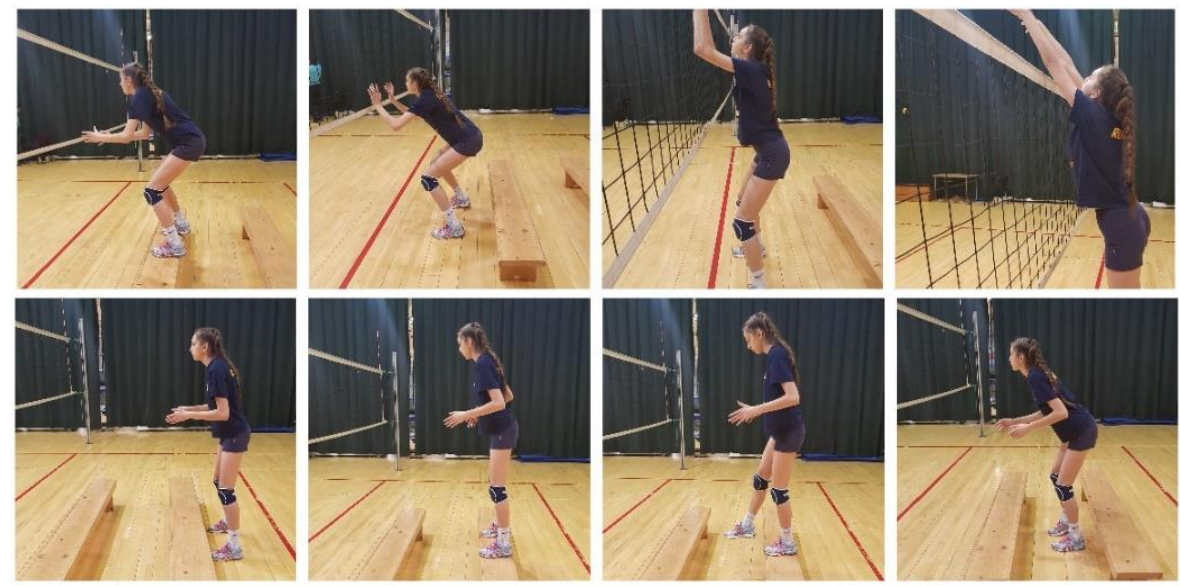

Fig. Exercise 8

\section{Findings}

After applying battery specific exercises to develop the expansion, we see an increase in values jump vertically for block final testing compared with the initial increased values jump vertically for attack, final testing than the original and also we can see an increase in triple jumping values at final testing compared to initial test.

Table 2. Difference in test environments

\begin{tabular}{lccc}
\hline \multirow{2}{*}{ Sample } & \multicolumn{2}{c}{ Test environments } & Difference of \\
& T.I. & T.F. & average \\
& (cm.) & (cm.) & 3,1 \\
\hline Vertical jump & 32,3 & 35,4 & 2,1 \\
Vertical jump with elan & 38,4 & 40,5 & 0,50 \\
Triple jump in length & 6,31 & 6,81 & \\
\hline
\end{tabular}

Analyzing table no. 2, we can affirm that there is a visible progress, even if the average difference is relatively small, exists and is due to the specially designed and implemented training program.

The difference in the positive values, reinforces the idea that progress is present in all three samples, and this is due to the training program specifically designed for the development of the combined motive quality, vertical jump. 
Adin-Marian COJOCARU et al. | Lumen Proceedings 9 | RSACVP2019

\section{Discussions}

Developing vertical jump is a major goal in training because it is an important skill for all volleyball players.

Plyometric training has a significant effect in increasing the power developed by muscle fibers specific to vertical loads, and Bosco "believes that by improving motor unit recruitment and improving the ability of muscles to store kinetic energy in elastic muscle components" [3]. Thus the strength of muscle fibers leads to an increase in the explosive capabilities of the athlete. This explosive transfer is extremely important in the volleyball game [1].

Regardless of the program chosen, it will start with the basic and intermediate exercises, then the intense ones, and finally we can use shock training with the performance athletes, trained. These exercises are always dynamic and explosive, in other words with energy and vitality, to improve the explosiveness and repeatability of movements and techniques.

When using this training method, specialists recommend that account be taken of the athlete's level of training and the intensity used in exercises. As with all phases of physical training, plyometric training must be subject to constant progress in the intensity and difficulty of exercises.

Between speed and force in speed, there are some differences that need to be known [7]:

Vertical jump is characterized by speed in force and must be developed with loads between $30-65 \%$ of the possibilities [2];

Force speed develops with loads ranging between $65-80 \%$ of the maximum possibilities, which can lead to increased explosive force indices [2].

\section{Conclusions}

As a result of the present study, the research hypothesis is confirmed by the fact that the use of exercises specifically designed for the development of detention has successfully developed this combined motor quality so important in the volleyball game.

The mottling quality vertical jump in the volleyball game is reported at the highest point of striking the ball in the attack action during a volleyball game, which is the essence of this research.

The higher results obtained in the final test compared to the initial test, entitles us to affirm that this is due to the exercises specifically designed and implemented in the team training program. 


\section{References}

[1] Adams K, O’Shea J, O'Shea K, Climstein M. The effect of six weeks of squat, plyometric and squat-plyometric training on power production, Journal of Applied Sport Science Research. 1992; 6(1):36-41.

[2] Alexandrescu D, Neamţu M. Atletism. 2000. Braşov: Editura Omnia Uni SAST. p. 151.

[3] Bosco C. Physiological consoderations of strength an explosive power and jumping drills. Proceedings of the Conference for Planning for Elite Performance, Aug. 1-5, Ottawa, Canada, CTFA; 1982., pp. 27-37.

[4] Colibaba-Evuleț D, Bota I. Jocuri sportive. Teorie şi metodică. Romania: Editura Aldin; 1998. p. 79.

[5] Dragnea AC, Mate-Teodorescu S. Teoria sportului. Bucureşti: Editura FEST; 2002.

[6] Hasegawa H, Dziados J, Newton RU, Fry AC, Kraemer WJ, Häkkinen K. Periodized training programmes for athletes. Strength training for sport, 2002;69:134.

[7] Iacob I, Păcuraru A. Volei - dezvoltarea calităţilor motrice. Iaşi: Editura Fundației Chemarea; 1999.

[8] Păcuraru A, Iacob I, Balaiş F, Braharu O. Manualul profesorului de volei. Iaşi: Editura HELIOS; 2000. p. 76.

[9] Powers ME. Vertical jump training for volleyball. Strength and Condo. 1996;18:18-23.

[10] Stanganelli LCR, Dourado AC, Oncken P, Mançan S, da Costa SC. Adaptations on jump capacity in Brazilian volleyball players prior to the under19 World Championship. The Journal of Strength \& Conditioning Research. 2008;22(3):741-749.

[11] Voigt HF, Vetter K. The value of strength-diagnostic for the structure of jump training in volleyball. European Journal of Sport Science. 2003;3(3):1-10.

[12] Ziv G, Lidor R. Vertical jump in female and male volleyball players: a review of observational and experimental studies. Scandinavian journal of medicine \& science in sports. 2010;20(4): 556-567. 